\begin{tabular}{|l|c|c|c|r|}
\hline $\begin{array}{l}\text { Cuadernos de Investigación Geográfica } \\
\text { Geographical Research Letters }\end{array}$ & 2018 & N $^{\circ} 44(1)$ & pp. 99-114 & $\begin{array}{r}\text { ISSN 0211-6820 } \\
\text { eISSN 1697-9540 }\end{array}$ \\
\hline
\end{tabular}

DOI: http://doi.org/10.18172/cig.3395

\title{
WHEN THE WEATHER TURNED BAD. THE RESEARCH OF CLIMATE IMPACTS ON SOCIETY AND ECONOMY DURING THE LITTLE ICE AGE IN EUROPE. AN OVERVIEW
}

\author{
CH. CAMENISCH ${ }^{1,2^{*}}$, CH. ROHR ${ }^{1,2}$ \\ ${ }^{1}$ Oeschger Centre for Climate Change Research, University of Bern, 3012 Bern, Switzerland. \\ ${ }^{2}$ Institute of History, Department of Economic, Social and Environmental History (WSU), \\ University of Bern, Länggassstrasse 49, 3012 Bern, Switzerland.
}

\begin{abstract}
This paper focusses on historical climate impact research, one of the branches of historical climatology with an emphasis on the Little Ice Age. It provides examples of the theoretical concepts, models, and further structuring considerations that are used in historical climate impact research, which are especially fitting to the examined period. We distinguish between the impact of climate on society by time-scale in long-term, conjunctural or medium-term, and short-term impacts. Moreover, a simplified climate-society interaction model developed by Daniel Krämer is presented, as well as the concept of the Little Ice Age-type Impact (LIATIMP) by Christian Pfister and the vulnerability concept regarding climatic variability and extreme weather events. Furthermore, the paper includes a state-of-the-art application of the historical climate impact research and discussion of research gaps.
\end{abstract}

Cuando el tiempo se volvió malo. La investigación de los impactos del clima en la sociedad y la economía durante la Pequeña Edad del Hielo en Europa

RESUMEN. Este trabajo se centra en el estudio del impacto histórico del clima, una de las ramas de la climatología histórica, en este caso en relación con la Pequeña Edad del Hielo. Proporciona ejemplos de conceptos teóricos, modelos, y consideraciones estructurales que se emplean en la investigación histórica del impacto climático. Distinguimos el impacto del clima en la sociedad a distintas escalas, a largo plazo, coyuntural o a medio plazo, y a corto plazo. Por otro lado, se presenta un modelo simplificado de interacción clima-sociedad desarrollado por Daniel Krämer, así como el concepto de impacto del tipo de la Pequeña Edad del Hielo de Christian Pfister y el concepto de vulnerabilidad en relación con la variabilidad climática y el impacto histórico del clima y de los eventos extremos. Finalmente, el trabajo incluye una actualización de la investigación sobre el impacto histórico del clima y una discusión acerca de las lagunas de investigación existentes. 
Key words: historical climatology, social history, economic history, Middle Ages, early Modern period, Little Ice Age.

Palabras clave: climatologia histórica, historia de la sociedad, historia económica, Edad Media, Edad Moderna, Pequeña Edad del Hielo.

Received: 2 August 2017

Accepted: 1 October 2017

*Corresponding author: Chantal Camenisch, Oeschger Centre for Climate Change Research, University of Bern, 3012 Bern, Switzerland. E-mail address: chantal. camenisch@hist.unibe.ch

\section{Introduction}

The "Little Ice Age" is a term introduced by geographer François Émile Matthes in the 1930s to depict a period of cooling temperatures on a global scale during the second millennium CE (Behringer, 2010). The beginning and the end of the Little Ice Age (LIA) is still part of a debate. Depending on the region and a focus on summer temperatures or on glacier movements, the beginning of the LIA is set either at the beginning of the 14th or during the second half of the 16th century (Lamb, 1982; Grove, 1988; Pfister, 1999; Fagan, 2000; Le Roy Ladurie, 2004; Miller et al., 2012; Matthews and Briffa, 2005; Brázdil et al., 2013; Glaser, 2013; Hoffmann, 2014). In this paper, the period between 1300 and 1850 is considered the LIA. It does not mean, however, that the climate was continuously cooler during that period; the temperature variability was extraordinary and LIA also contains periods of remarkable heat (Landsberg, 1985; Pfister, 1999). An example is the year 1540 with an unusual heat wave and drought in Europe (e.g. Wetter and Pfister, 2013; Wetter et al., 2014).

Historical climatology is a research field, which is situated between climatology and environmental history. In it, researchers examine the climate of the past based on documentary data from man-made archives (in a broad sense and including archaeological finds). Historical climatology comprises three branches of which the first concerns the reconstruction of climate, the second examines the societal impact of climate, and the third deals with the perception of climate and the history of knowledge of climate (Pfister, 1999; Brázdil et al., 2005; Mauelshagen, 2010; Mauelshagen and Pfister, 2010).

This paper focusses on the second branch, or the societal climate impacts during the LIA in Europe. The paper aims to present concepts and models used in that field and a state of the art application of it. There are several existing state-of-the art papers, one of which gives an excellent overview on the three fields of historical climatology (Brázdil et al., 2005). Because the field of historical climate impact research is very productive, it is worthwhile to reassess the state of the art from time to time - especially for research in appreciated epochs like the LIA. In addition, the paper will show research gaps and desiderata in the mentioned topic. 


\section{State of the Art}

\subsection{Concepts and models}

Societal climate impacts can be structured not only in time but also in different levels of direct and indirect interaction between climate and society. Jan de Vries (1980) proposed a distinction between long-term, conjunctural, and short-term climate impacts on society, which also was discussed in the edited volume by Wigley et al. (1981). Such a distinction in the time-scale of the climate impacts on society is useful because it gathers similar events and invites a comparison of them over time and space; moreover, it shows how broad the range of climate impact types can be.

More recently, Krämer (2015) proposed a simplified climate-society interaction model, which has reached a broad impact (Luterbacher and Pfister, 2015). It was originally developed and enhanced from former attempts to explain the link between climate and society (e.g. Ingram et al., 1981; Pfister, 1984, 2005). In this model, Krämer (2015) and Luterbacher and Pfister (2015) assume that climate variability and natural disasters -especially temperature and precipitation anomalies and further extreme events such as floods, droughts, storms, hail, and (forest) fires- cause first-order impacts on a bio-physical level. These first-order impacts include the primary production of biomass (food, feed, and fuelwood), water availability and the development of microorganisms. On the second level, prices of biomass and energy as well as transportation are affected. On the same level, the spread of epidemic and epizootic diseases is influenced by weather conditions (cf. Newfield, 2009; Slavin, 2012; Hoffmann, 2014; Campbell, 2016). Depending on the disease, e.g. humid and cool weather can favour or hamper the spread. As result, malnutrition, the decline of demographic growth and social conflicts are settled on the third level. On the fourth level, cultural responses such as crisis interpretation, cultural memory and learning processes are affected.

The influences of climate variability decrease on every ascending level because more and more other factors become important as well. As the model shows, there is a second branch of impact cascading from the fourth level to the first level. In this second cascade, religious rituals, amendments and various further adaptation strategies on the fourth level influence the third level, especially on grain supply, migration and public and private welfare. This can lead to market interventions, an expansion of the networks of terrestrial and waterway transport, and the linked infrastructure on the second level as well as a diversification of planted crops and the use of parcels in different altitudes and exposures on the first level. Finally, this first level can have an impact on climate variations, the appearance of extreme weather events, and so on. In this second cascade, the influence declines with every descending level.

Pfister (2005, 2007a) introduced the term "Little Ice Age-type Impact" (LIATIMP) to explain a specific type of climate impact on society which, in Central Europe, mainly caused by chilly springs and rainy mid-summers. This LIATIMP could concern the grain production through an elevated amount of precipitation. In autumn and winter, this would reduce the calcium, phosphates and nitrogen content of the soil. Extended rain in autumn furthermore would hamper the sowing of winter grain. Rain periods prior and 
during the harvest would reduce the flour content of the grain corn and therefore the amount of food. It also would lead to the stored grain being more vulnerable to the spread of the grain weevil, other insects, infections and fungi (Pfister, 2005; Camenisch, 2015). A long-lasting snow cover until April could promote the spread of snow-mold and low temperatures in April would lower the yield of grain (Pfister, 2005). Low temperatures in winter, which lasted until late spring, could furthermore delay the growing of the plants and therefore lead to a late harvest, when the weather conditions already were more variable and less secure. Frost periods in April and May would cause great losses in the grain production as well (Camenisch et al., 2016).

Regarding dairy production, the milk yield of the cattle such as cows and goats were dependent on the amount of daily available food (e.g. grass, hay) for the animal. This feed amount, however, was influenced by the duration of the snow cover and the temperatures in autumn and spring (Bracher, 2016). A poor hay harvest had an impact on the amount of milk in the subsequent winter. In this context, it is important to remember that the purpose of cattle breeding was not limited to milk production but also to obtain animal protein for human nutrition, the gain of muscle power by using draft animals for ploughing, manure production, leather production, and so on (Pfister, 2005). Wine production also depended on favourable weather conditions. Like grain, vine plants are sensitive to frosts in April and May. Wet spells from late June to early August would greatly reduce the size of the grape harvest. In contrast, the sugar content of the grapes is dependent on a warm and sunny period immediately before harvest, in September and early October. The LIATIMP comprises crop failures like those described not as single events but as widespread crop failure of several crops (Pfister, 2005).

The concept of vulnerability is often used to assess societal impacts of climate and natural disasters (e.g. Adger, 2006; Pfister and Brázdil, 2006; Füssel and Klein, 2006; Voss, 2008; Pfister, 2010; Collet, 2012; Collet et al., 2012; Engler, 2012; Krämer, 2012, 2015; Curtis, 2014). In this concept, a system is vulnerable to certain hazards (e.g. extreme weather conditions). The type and number of the stressors, their root causes, the effects on the systems as well the time horizon of the analysis are decisive (Füssel, 2007). To assess the vulnerability of a certain part of a system such as an individual, household, society, state, animal plan or ecological system, it is necessary to know more about the exposure of the object and how often it is affected by a hazard. Furthermore, it is important to know the sensitivity of a system or to what extent it will be changed by bio-physical, socioeconomic and political processes caused by the hazard. Finally, the resilience of the object and its adaptation strategies must be considered (Krämer, 2015).

Vulnerability factors can be classified into the dimensions of sphere and knowledge domain. Within this frame, there are internal and external factors on the one hand and socioeconomic and biophysical factors on the other hand. As Füssel (2007) described, "Taken together, these four categories constitute the vulnerability profile of a particular system or community to a specific hazard at a given point in time". As Füssel (2007) and later Krämer $(2012,2015)$ demonstrated, the vulnerability factors of the biophysical domain's internal sphere include topography, environmental conditions, land cover and soil conditions. The factors of the external sphere comprise non-weather-related natural hazards (e.g. earthquakes), 
weather anomalies, and extreme weather events (e.g. severe storms, or sea-level changes) as well as epidemic and epizootic diseases. In the socioeconomic domain, the internal sphere includes household income, social networks and access to information whereas the external sphere is composed of national policies, international aid, economic globalization, wars, taxes and fees, grain export bans and embargoes.

\subsection{State of the art}

\subsubsection{Climate impacts by time-scale}

The origin of the modern climate impact research goes back to a conference organised by Hubert Horace Lamb in Norwich in 1979. The resulting edited volume with the main findings not only represents the state of the art at that moment, it also shows the enthusiasm of the mostly young researchers then. Many of the results still are topical and of great value (Wigley et al., 1981; therein e.g. Anderson, 1981; Flohn, 1981; Lamb, 1981; Mackay, 1981; Parry, 1981). In the same year, an edited volume by Rotberg and Rabb (1981) appeared with a focus on climate impacts on society, which also contributed with useful methodological thoughts (e.g. Appleby, 1981; de Vries, 1981; Post, 1981). A further early milestone are the papers edited by Kates, Ausubel, and Berberian in 1985 (therein e.g. de Vries, 1985; Kates, 1985; Wigley et al., 1985). As already mentioned, de Vries (1980) proposed a distinction between long-term, conjunctural, and short-term climate impacts on society. In the following sub-chapters, publications focussing on the societal impact of climate during the LIA will be presented.

\subsubsection{Long-term impacts}

Amongst the long-term impacts are the collapse of empires, migration of nations or similar epochal events. In this time-scale especially, the studies of Braudel (1949) and Lopez (1962) need to be mentioned. More recent are the findings of White (2011) who sets the change of political structure in the Ottoman Empire during the 16th and 17th century in the context of the climate of the LIA. Furthermore, Parker (2013) showed the link between climate change and severe political and demographic crises in mighty empires across the world in the mid-17th century. McNeill (2010), however, did not only look on the climatic impact on the rise and fall of empires in Central America, but also on the influence of the whole eco-system. Moreover, Wanner (2016) published an overview on climate and human beings during the last 12,000 years. As a matter of course, all these authors clearly show that climate is one factor of several and there is no mono-causal explanation for complex societal change.

\subsubsection{Conjunctural or medium-term impacts}

Medium-term or conjunctural impacts are understood as climate impacts on society that have a repetitive inter-annual influence. Regarding these impacts, de Vries (1980) focussed on the influence of weather conditions on harvest size and the prices of bread grain. The analysis of grain prices has a long tradition and most of the researchers operating in this field acknowledge an influence of weather conditions on prices (e.g. Beveridge, 1921, 1922; van der Wee, 1963; Brandon, 1971; Neveux, 1974; Braudel, 
1979; Bauernfeind, 1993; Bauernfeind and Woitek, 1996; Bauernfeind et al., 2001). Nonetheless, except for Pfister (1975, 1984, 1988, 2004), these authors could not examine the relation between weather conditions and prices in detail due to the lack of reliable climate data for the LIA in those years.

In 1981, de Vries assumed that the link between weather and prices was not as close as one could expect. The statistical correlations between weather conditions and tithe data, for instance, are rather weak as demonstrated by Bowden (1967) and Pfister (1975). Later, Pfister $(1984,1988)$ used more elaborated methods and better data on the reconstructed climate and consequently proved a closer link between climate and grain prices. Also for the Burgundian Low Countries in the late Middle Ages, it was possible to give evidence for a close relation between seasonal climate indices and grain prices (Camenisch, 2015). Decisive in that matter was the availability of high-resolution climate data. In epochs before instrumental measurement, this is only possible when enough sources of essential quality exist for the examined region and period. Moreover, in sources of the late Middle Ages and early modern period, the link between weather conditions and prices seems to be closer than between weather conditions and crop yields. The reason for this is most likely the fact that prices usually represent an extended geographical area whereas data on crop yields derive from a much smaller area - a couple of fields, for instance. Both prices and tithes or other yield data are influenced by many other factors beyond weather conditions anyway (Camenisch, 2015).

Ingram et al. (1981) proposed to add the impact of medium-term, interannual climatic fluctuations to this category. This encloses clusters of extreme seasons and individual weather events. For this paper, we decided that at least three consecutive years of impacts were necessary for a classification as a medium-term impact. The societal impact of such clusters regarded as medium-term also has been examined for the LIA. Examples of this include the 1430s - a cluster of extremely cold winter seasons (Camenisch et al., 2016) - and the 1680s and 1690s, which was the coldest phase of the Late Maunder Minimum (1675-1715 CE) with a very specific climate pattern (Lamb, 1982; Lachiver, 1991; Barriendos, 1997; Luterbacher et al., 2001; Zwitter, 2015).

\subsubsection{Short-term impacts}

The impact of short-term weather extremes and variability as well as weatherinduced natural disasters is the object of many analyses. Amongst these short-term impacts, the research on subsistence crises plays a major role. Because subsistence crises also take a very prominent place within the model presented by Krämer (2015), they are discussed in section 2.2.2 in more detail.

Regarding short-term impacts, natural disasters induced by extreme weather must be mentioned. A couple of rather recent publications include the societal impact of this type of natural disasters (Kempe and Rohr, 2003; Rohr, 2007, 2008; Schenk and Engels, 2007). Amongst those disasters are storm surges (Jakubowski-Tiessen, 1992; de Kraker, 2000, 2002, 2005; Soens, 2013), avalanches (e.g. Rohr, 2009a), floods (Brázdil et al., 2010; Rohr, 2005, 2006, 2012a, 2012b, 2013; Kiss, 2018), and locust invasions (Rohr, 2009b, 2014). 
It is necessary, however, to be conscious of the limits of such a distinction between the possible different time scales: series of short-term impacts may form a conjunctural or medium-term impact. Also long-term impacts contain short-term impacts and conjunctural or medium-term impacts. Therefore, one should be aware that this timerelated distinction is a structure that shall lead to a better understanding of the societal climate impacts and not be an axiomatic certainty.

\subsubsection{Climate impacts by impact-level}

Climate impacts on society also may be structured by following the simplified climate-society interaction model presented above. This structure presents the results of analyses including societal impacts (e.g. Camenisch et al., 2016).

Amongst the first-order impacts, the production of biomass is very important. Hence, there are few studies analysing the relation between weather conditions and grain crop yields (e.g. Pfister, 1981a; Bourke, 1984; Stern, 2000; Franzén and Söderberg, 2006; Litzenburger, 2015). More data exist on wine production where often the harvest date plays an important role for climate reconstructions. Some of these analyses also included the quantity of wine harvest into their considerations (e.g. Pfister, 1981b, 1984; Kiss et al., 2011; Litzenburger, 2015).

Rising food prices and consequently subsistence crises as an extreme case of high food prices occurred repeatedly during the LIA (Collet and Schuh, 2018). A subsistence crisis always is caused by many different factors, but not only by adverse weather conditions and rising food prices (Camenisch, 2015; Krämer, 2015). Many famines already have been examined for certain regions. The Great Famine from 1315 to 1320 is one of two harsh demographic crises that hit European society during the 14th century (Jordan, 1998; Campbell, 2009, 2016; Huhtamaa, 2015; Slavin, 2017). The famines of the 1430s, 1480s, and 1490s also must be mentioned (Jörg, 2008; Camenisch, 2015; Camenisch et al., 2016). A couple of the great subsistence crises of the 16th, 17th, and 18th centuries have also been examined for certain regions in Europe (and the world) (Lachiver, 1991; Le Roy Ladurie, 2004, 2006; Parker, 2013).

Due to the bicentenary of the Tambora eruption in 1815 and the following famine in 1816 and 1817, a couple of publications dealt with the extreme weather events and seasonal anomalies caused by the volcanic eruption in Indonesia and its impact on society (D’Arcy Wood, 2014; Krämer, 2015; Luterbacher and Pfister, 2015; Behringer, 2015; Brönnimann and Krämer, 2016, Flückiger et al., 2017).

Regarding human and animal epidemic diseases linked to climate, Campbell's (2016) pathbreaking work must be mentioned as well as recent findings focussing on cattle (Newfield, 2009; Slavin, 2012).

Amongst the fourth-order impacts are a variety of phenomena and processes. Many of them are described in a volume edited by Behringer et al. (2005). It would go too far at this place to discuss each of them. Instead, a few examples shall be presented. The perception and interpretation of natural hazards and extreme weather events are crucial for the understanding of the interaction between climate and society. There is already 
in-depth research done in this field, especially for the Eastern Alpine area (Rohr, 2003, 2007, 2008). Examinations of the religious rituals used as a coping strategy are found in works by Barriendos (1997, 2005), Bauch (2016) and Jakubowski-Tiessen and Lehmann (2003). The phenomenon of scapegoat hunting, which includes pogroms against Jewish individuals and societies, witch hunting, and the hunt for religious and social minorities, has also been examined in recent years (Behringer, 1995, 1999, 2004; Pfister, 2007b).

\section{Desiderata}

As we have shown above, a considerable number of studies published in the last years has focussed on the societal impact of climate during the LIA. Nonetheless, we need more research in this field, especially further in-depth studies of not-yet-explored source material across Europe. There is plenty of evidence in historical archives, which has never been examined under the question of climatic impact on society. It is necessary to bring results from a wider geographical area together to assess the magnitude of events and to compare the impacts and the coping and adaption strategies of societies from different places and in different environments.

Also, areas that are not in the very centre of Europe play a very important role. Although there are recent publications (e.g. Ogilvie and Jonsson, 2001; Huhtamaa, 2015, for the example of border regions in Scandinavia), there are still huge gaps. On the one hand, information from Scandinavia, Ireland, Bohemia, or South Italy helps to estimate the dimensions of drought impacts, famine, or the spread of an epidemic disease. On the other hand, they often show different coping strategies. For instance, the peasants in Finland applying slash-and-burn agriculture and having access to deer hunting and fishery that was not regulated by the government (Huhtamaa and Helama, 2017) had different coping strategies against extreme weather than the citizens of the prosperous metropolises of the Low Countries.

Moreover, further research on all levels of Krämer's model would be appreciated. More studies on crop yields, for instance, would help to close the gap between the weather and prices. It also would bring together two parts of the same society: the countryside where the crops were produced and the urban sphere where the prices were made on the markets.

As Campbell (2016) has shown with his recent masterpiece, there are stunning links between the epidemic disease of the Black Death (Yersinia pestis) and climatic variability. Later plague waves or the link between other epidemic diseases are investigated much less. The demographic impact of extreme weather and natural disasters needs to be investigated further as well as the fourth-order impacts of these phenomena. The crisis interpretation and learning processes are promising fields, which particularly need more research.

\section{Conclusions}

Within historical climatology, the research on climate impacts on society is of considerable importance. Although the reconstruction of climate based on historical sources is settled on the interface between natural sciences and environmental history, 
historical climate impact research is linked more closely to economic and social sciences and history.

To understand the complex relationship between climate and society, historical climate impact research is dependent on classifications, models and theoretical concepts. Amongst them are those presented in this paper. The classification following a division of climate impacts on society by time scale, as well as the climate-society interaction model, the LIA-type impacts and the concept of vulnerability are useful in understanding and interpreting climate and society.

Historical climate impact research is a very productive research field, and recently many new results have been published. By far, not all recent and important publications could be listed in this paper, but this overview should give an impression of the most important papers, monographs and edited volumes. Nonetheless, there are many gaps in the research field including many (archival) sources which were never investigated in all areas of Europe but especially for Scandinavia, Ireland, Bohemia, South Italy, or the Balkans and desiderata at all different levels of climate impacts, notably on crop yields, the interaction between weather conditions and diseases, crisis interpretation, or learning processes.

\section{References}

Adger, N. 2006. Vulnerability. Global Environmental Change 16,268-281. http://doi.org/10.1016/j. gloenvcha.2006.02.006.

Anderson, J.L. 1981. History and climate. Some economic models. In: T.M.L. Wigley, M.J. Ingram, G. Farmer (Eds.), Climate and history. studies in past climates and their impact on man. Cambridge University Press, Cambridge, pp. 337-355.

Appleby, A.B. 1981. Epidemics and famine in the Little Ice Age. In: R.I. Rotberg, T.K. Rabb (Eds.), Climate and History. Studies in Interdisciplinary History. Princeton University Press, Princeton, pp. 63-83. https://doi.org/10.1515/9781400854103.63.

Barriendos, M. 1997. Climatic variations in the Iberian Peninsula during the Late Maunder Minimum (AD 1675-1715). An analysis of data from rogation ceremonies. The Holocene 7 (1), 105-111. https://doi.org/10.1177/09596836900700110.

Barriendos, M. 2005. Climate and culture in Spain. Religious responses to extreme climatic events in the Hispanic kingdoms (16th-19th centuries). In: W. Behringer, H. Lehmann, C. Pfister (Eds.), Kulturelle Konsequenzen der "Kleinen Eiszeit"/Cultural consequences of the "Little Ice Age”. Veröffentlichungen des Max-Planck-Instituts für Geschichte 212. Vandenhoeck \& Ruprecht, Göttingen, pp. 379-414.

Bauch,M.2016.Der Regen, das Korn und das Salz: die Madonna di San Luca und das Wettermirakel von 1433. Eine klimahistorische Fallstudie zu Bologna und Italien in den 1430er Jahren. Quellen und Forschungen aus italienischen Archiven und Bibliotheken 95, 183-212. https:// doi.org/10.1515/qfiab-2015-0008.

Bauernfeind, W. 1993. Materielle Grundstrukturen im Spätmittelalter und der Frühen Neuzeit. Preisentwicklung und Agrarkonjunktur am Nürnberger Getreidemarkt von 1339 bis 1670, Nürnberger Werkstücke zur Stadt- und Landesgeschichte 50. Stadtarchiv, Nürnberg, 544 pp. https://doi.org/10.1006/exeh.1996.0025

Bauernfeind, W., Reutter, M., Woitek, U. 2001. Rational investment behaviour and seasonality in early modern grain prices. European Review of Economic History 5 (2), 281-298. 
Bauernfeind, W., Woitek, U. 1996. Agrarian cycles in Germany 1339-1670: A spectral analysis of grain prices and output in Nuremberg. Explorations in Economic History 33 (4), 459-478.

Behringer, W. 1995. Weather, hunger and fear. Origins of the European witch-hunts in Climate, Society and Mentality. German History 13 (1), 1-27.

Behringer, W. 1999. Climatic change and witch-hunting. The impact of the Little Ice Age on mentalities. Climatic Change 43 (1), Special issue: Climatic variability in sixteenth century Europe and its social dimension, C. Pfister, R. Brázdil, R. Glaser (Eds.), pp. 335-351.

Behringer, W. 2004. Witches and witch-hunts: A global history. Polity Press, Cambridge, 360 pp.

Behringer, W. 2010. A Cultural history of climate. Polity Press, Cambridge, 295 pp.

Behringer, W. 2015. Tambora und das Jahr ohne Sommer. Wie ein Vulkan die Welt in die Krise stürzte. Beck, München, 398 pp. https://doi.org/10.17104/9783406676161.

Behringer, W., Lehmann, H., Pfister, C. (Eds.). 2005. Kulturelle Konsequenzen der "Kleinen Eiszeit"/Cultural consequences of the "Little Ice Age". Veröffentlichungen des Max-PlanckInstituts für Geschichte 212. Vandenhoeck \& Ruprecht, Göttingen, 514 pp.

Beveridge, W.H. 1921. Weather and harvest cycles. The Economic Journal 31, pp. 429-452. https:// doi.org/10.2307/2223074.

Beveridge, W.H. 1922. Wheat prices and rainfall in Western Europe. Journal of the Royal Statistical Society 85 (3), 412-475. https://doi.org/10.2307/2341183.

Bourke, A. 1984. The impact of climatic fluctuations on agriculture. In: H. Flohn, R. Fantechi (Eds.), The climate of Europe - Past, present and future. Kluwer, Dordrecht, pp. 269-314.

Bowden, P. 1967. Agricultural prices, farm profits, and rents. In: J. Thirsk (Ed.), The agrarian history of England and Wales, vol. 4, 1500-1640. Cambridge University Press, Cambridge, pp. 593-695.

Bracher, C. 2016. Die vorindustrielle Alpwirtschaft im Oberwallis aus klima- und wirtschaftshistorischer Perspektive. Eine Fallstudie aus dem Binntal und Simplongebiet 1770-1835. Blätter aus der Walliser Geschichte 48, 1-183.

Brandon,P.F. 1971.Late-Medieval weather in Sussex and its agricultural significance. Transactions of the Institute of British Geographers 54, 1-17. https://doi.org/10.2307/621358.

Braudel, F. 1949. Le Méditerranée et le monde méditerranéen à L'époque de Philippe II. Armand Colin, Paris, $1160 \mathrm{pp}$

Braudel, F. 1979. Civilisation matérielle, économie et capitalisme.XVe-XVIIIe siècle, 3 vol. Colin, Paris 1979.

Brázdil, R., Demarée, G.R., Deutsch, M., Garnier, E., Kiss, A., Luterbacher, J., Macdonald, N., Rohr, C., Dobrovolný, P., Koláŕ, P., Chromá, K. 2010. European floods during the winter 1783/1784: Scenarios of an extreme event during the "Little Ice Age". Theoretical and Applied Climatology 100, 163-189. https://doi.org/10.1007/s00704-009-0170-5.

Brázdil, R., Kotyza, K., Dobrovolný, P., Řezníčková, L., Valášek, H. 2013. Climate of the sixteenth century in the Czech lands. Masaryk University, Brno, 285 pp.

Brázdil, R., Pfister, C., Wanner, H., von Storch, H., Luterbacher, J. 2005. Historical climatology in Europe - The state of the art. Climatic Change 70, 363-430, https://doi.org/10.1007/s10584005-5924-1.

Brönnimann, S., Krämer, D. 2016. Tambora and the "year without a summer" of 1816. A perspective on Earth and human systems science. Geographica Bernensia G90, 48 pp. http:// doi.org/10.4480/GB2016.G90.01.

Camenisch, C. 2015. Endlose Kälte. Witterungsverlauf und Getreidepreise in den Burgundischen Niederlanden im 15. Jahrhundert, Wirtschafts-, Sozial- und Umweltgeschichte (WSU) 5. Schwabe, Basel, 523 pp. https://doi.org/10.26530/OAPEN_587970.

Camenisch, C., Keller, K.M., Salvisberg, M., Amann, B., Bauch, M., Blumer, S., Brázdil, R., Brönnimann, S., Büntgen, U., Campbell, B.M.S., Fernández-Donado, L., Glaser, R., 
González-Rouco, F., Grosjean, M., Hoffmann, R.C., Huhtamaa, H., Joos, F., Kiss, A., Kotyza, O., Lehner, F., Luterbacher, J., Maughan, N., Neukom, R., Novy, T., Pribyl, K., Raible, C.C., Riemann, D., Schuh, M., Slavin, P., Wetter, O. 2016. The 1430s: A cold period of extraordinary internal climate variability during the early Spörer Minimum with social and economic impacts in North-western and Central Europe. Climate of the Past 12, 2107-2126. http://doi.org/10.5194/cp-12-2107-2016.

Campbell, B.M.S. 2009. Four famines and a pestilence: Harvest, price, and wage variations in England, 13th to 19th centuries. In: B. Liljewall, I.A. Flygare, U. Lange, L. Ljunggren, J. Söderberg (Eds.), Agrarhistoria på många sätt; 28 studier om manniskan och jorden. Festskrift till Janken Myrdal på hans 60-årsdag. Agrarian history many ways: 28 studies on humans and the land, Festschrift to Janke Myrdal 2009. KSLAB, Stockholm, Sweden, pp. 23-56.

Campbell, B.M.S. 2016. The great transition: Climate, disease and society in the latemedieval world. Cambridge University Press, Cambridge, 485 pp. https://doi.org/10.1017/ CBO9781139031110.

Collet, D. 2012. "Vulnerabilität" als Brückenkonzept der Hungerforschung. In: D. Collet, T. Lassen, A. Schanbacher (Eds.) Handeln in Hungerkrisen. Neue Perspektiven auf Soziale und Klimatische Vulnerabilität. Universitätsverlag Göttingen, Göttingen, pp. 13-25.

Collet, D., Lassen, T., Schanbacher, A. (Eds.). 2012. Handeln in Hungerkrisen. Neue Perspektiven auf soziale und klimatische Vulnerabilität. Universitätsverlag Göttingen, Göttingen, 245 pp.

Collet, D., Schuh, M. 2018. Famines during the "Little Ice Age" (1300-1800). Socionatural Entanglements in Premodern Societies. Springer, Berlin (forthcoming).

Curtis, D.R. 2014. Coping with crisis: The resilience and vulnerability of pre-industrial settlements. Ashgate Publishing, Burlington, $381 \mathrm{pp}$.

D'Arcy Wood, G. 2014. Tambora. The eruption that changed the world. Princeton University Press, Princeton, 293 pp.

De Kraker, A.M.J. 2000. Storm surges, high tides and storms as extreme weather events, their impact on the coastal zone of the North Sea and the human response, 1350 to 2000. In: B. Obrebska-Starkel (Ed.), Reconstructions of climate and its modelling. Millennium images and reconstructions of weather and climate over the last Millennium. Prace Geograficzne 107. Institut of Geography of the Jagiellonian University, Crakow, pp. 85-101.

De Kraker, A.M.J. 2002. Historic storms in the North Sea area, an assessment of the storm data, the present position of research and the prospects for future research. In: G. Wefer, W. Berger, K.-E. Behre, E. Jansen (Eds.), Climate development and history of the North Sea realm. Springer, Berlin, pp. 415-434. https://doi.org/10.1007/978-3-662-04965-5_27.

De Kraker, A.M.J. 2005. Reconstruction of storm frequency in the North Sea area of the preindustrial period, 1400-1625 and the connection with reconstructed time series of temperatures. History of Meteorology 2, Special issue: Diversity in the global reconstruction and representation of weather and climate: east, south, west, north. Selected Papers from the ICHM Symposium at the International Congress of History of Science, Beijing, China, July 2005, L.K. McNally III, C. Rohr (Eds.), pp. 51-69, http://www.meteohistory. org/2005historyofmeteorology2/05dekraker.pdf.

De Vries, J. 1980. Measuring the impact of climate on history: The search for appropriate methodologies. The Journal of Interdisciplinary History 10 (4), 599-630. https://doi. org/10.2307/203061.

De Vries, J. 1981. Measuring the impact of climate on history. The search for appropriate methodologies. In: R.I. Rotberg, T.K. Rabb (Eds.), Climate and history. Studies in interdisciplinary history. Princeton University Press, Princeton, pp. 19-50 (originally published as de Vries, 1980). 
De Vries, J. 1985. Analysis of historical climate-society interaction. In: R.W. Kates, J.H. Ausubel, M. Berberian (Eds.), Climate impact assessment. Studies of the interaction of climate and society. Scope 27, John Wiley, Chichester, pp. 273-291.

Engler, S. 2012. Hungersnot - Bekannte Theorien und neue Analysemodelle. In: D. Collet, T. Lassen, A. Schanbacher (Eds.), Handeln in Hungerkrisen. Neue Perspektiven auf soziale und klimatische Vulnerabilität. Universitätsverlag Göttingen, Göttingen, pp. 67-83.

Fagan, B. 2000. The Little Ice Age. How climate made history 1300-1850. Basic Book, New York, $246 \mathrm{pp}$.

Flohn, H. 1981. Short-term climatic fluctuations and their economic role. In: T.M.L. Wigley, M.J. Ingram, G. Farmer (Eds.), Climate and history. Studies in past climates and their impact on man. Cambridge University Press, Cambridge, pp. 310-318.

Flückiger, S., Brönnimann, S., Holzkämper, A., Fuhrer, J., Krämer, D., Pfister, C., Rohr, C. 2017. Simulating crop yield losses in Switzerland for historical and present Tambora climate scenarios. Environmental Research Letters 12 (7). https://doi.org/10.1088/1748-9326/ aa7246.

Franzén, B., Söderberg, J. 2006. Svenska Spannmålspriser Under Medeltiden I ett Europeiskt Perspektiv. Historisk Tidskrift 126 (2), 189-214.

Füssel, H.-M. 2007. Vulnerability: A generally applicable conceptual framework for climate change research. Global Environmental Change 17 (2), 155-167. https://doi.org/10.1016/j. gloenvcha.2006.05.002.

Füssel, H.-M., Klein, R.T. 2006. Climate change vulnerability assessments: An evolution of conceptual thinking. Climatic Change 75, 301-329. https://doi.org/10.1007/s10584-0060329-3.

Glaser, R. 2013. Klimageschichte Mitteleuropas. 1200 Jahre Wetter, Klima, Katastrophen. Mit Prognosen für das 21. Jahrhundert. Primus, Darmstadt, 264 pp.

Grove, J.M. 1988. The Little Ice Age. Methuen, London, 498 pp. https://doi. org/10.4324/9780203402863.

Hoffmann, R.C. 2014. An environmental history of Medieval Europe. Cambridge University Press, Cambridge, 409 pp. https://doi.org/10.1017/CBO9781139050937.

Huhtamaa, H. 2015. Climatic anomalies, food systems, and subsistence crises in Medieval Novgorod and Ladoga. Scandinavian Journal of History 40 (4), 562-590. https://doi.org/10. 1080/03468755.2015.1063081.

Huhtamaa, H., Helama, S. 2017. Reconstructing crop yield variability in Finland: Long-term perspective of the cultivation history on the agricultural periphery since ad 760. The Holocene 27 (1), 3-11. https://doi.org/10.1177/0959683616646188.

Ingram, M.J., Farmer, G., Wigley, T.M.L. 1981. Past climates and their impact on man: A review. In: T.M.L. Wigley, M.J. Ingram, G. Farmer (Eds.), Climate and history. Studies in past climates and their impact on man. Cambridge University Press, Cambridge, pp. 3-50.

Jakubowski-Tiessen, M. 1992. Sturmflut 1717. Die Bewältigung einer Naturkatastrophe in der Frühen Neuzeit, Ancien Régime, Aufklärung und Revolution 24. Oldenbourg, Münschen, $350 \mathrm{pp}$.

Jakubowski-Tiessen, M., Lehmann, H. (Eds.). 2003. Um Himmels Willen: Religion in Katastrophenzeiten. Vandenhoeck \& Ruprecht, Göttingen, 538 pp.

Jordan, W.C. 1998. The Great Famine. Northern Europe in the early fourteenth century. Princeton University Press, Princeton.

Jörg, C. 2008. Teure, Hunger, Großes Sterben. Hungersnöte und Versorgungskrisen in den Städten des Reiches während des 15. Jahrhunderts, Monographien zur Geschichte des Mittelalters 55, Anton Hiersemann, Stuttgart, 464 pp. 
Kates, R.W. 1985. The interaction of climate and society. In: R.W. Kates, J.H. Ausubel, M. Berberian (Eds.), Climate impact assessment. Studies of the interaction of climate and society. Scope 27, John Wiley, Chichester, pp. 3-36.

Kates, R.W., Ausubel, J.H., Berberian, M. (Eds.). 1985. Climate impact assessment. Studies of the interaction of climate and society, Scope 27, John Wiley, Chichester, 625 pp.

Kempe, M., Rohr, C. (Eds.). 2003. Coping with the unexpected. Natural disasters and their perception, Environment and History 9 (2), Special Issue, 128 pp.

Kiss, A., Wilson, R., Bariska, I. 2011. An Experimental 392-year documentary-based multiproxy (vine and grain) reconstruction of may-july temperatures for Köszeg, West-Hungary. International Journal of Biometeorology 55 (4), 595-611. https://doi.org/10.1007/s00484010-0367-4.

Kiss, A. 2018 (in press). Floods and long-term water-level changes in Medieval Hungary. Springer, Berlin, 499 pp.

Krämer, D. 2012. Vulnerabilität und die konzeptionellen Strukturen des Hungers. Eine methodische Annäherung. In: D. Collet, T. Lassen, A. Schanbacher (Eds.), Handeln in Hungerkrisen. Neue Perspektiven auf soziale und klimatische Vulnerabilität. Universitätsverlag Göttingen, Göttingen, pp. 45-65.

Krämer, D. 2015. "Menschen grasten nun mit dem Vieh". Die letzte grosse Hungerkrise der Schweiz, 1816/17. Mit einer theoretischen und methodischen Einführung in die historische Hungerforschung. Wirtschafts-, Sozial- und Umweltgeschichte (WSU) 4. Schwabe, Basel, $527 \mathrm{pp}$.

Lachiver, M. 1991. Les années de misère. La famine au temps du Grand Roi 1680-1720. Fayard, Paris, $573 \mathrm{pp}$.

Lamb, H.H. 1981. An approach to the study of the development of climate and its impact in human affairs. In Climate and history. Studies in past climates and their impact on man, T.M.L. Wigley, M.J. Ingram, G. Farmer (Eds.). Cambridge University Press, Cambridge, pp. 291309.

Lamb, H.H. 1982. Climate history and the modern world. Methuen, London, 387 pp. https://doi. org/10.4324/9780203433652.

Landsberg, H.E. 1985. Historical weather data and early meteorological observations. In: A. D. Hecht (Ed.), Paleoclimate analysis and modelling. John Wiley, New York, pp. 27-70.

Le Roy Ladurie, E. 2004. Histoire humaine et comparée du climat, vol. 1: Canicules et glaciers XIIIe-XVIIIe siècles. Fayard, Paris, 748 pp.

Le Roy Ladurie, E. 2006. Histoire humaine et comparée du climat, vol. 2: Disettes et révolutions (1740-1860). Fayard, Paris, 611 pp.

Litzenburger, L. 2015. Une ville face au climat: Metz à la fin du Moyen Âge, 1400-1530. Presses universitaires de Nancy, Nancy 2015, 488 pp.

Lopez, R.S. 1962. La naissance de l'Europe. Armand Colin, Paris, 487 pp.

Luterbacher, J., Rickli, R., Xoplaki, E., Tinguely, C., Beck, C., Pfister, C., Wanner, H. 2001. The late Maunder Minimum (1675-1715) - A key period for studying decadal scale climatic change in Europe. Climatic Change 49, 441-462. https://doi.org/10.1023/A:1010667524422.

Luterbacher, J., Pfister, C. 2015. The year without a summer. Nature Geoscience 8, 246-248. https://doi.org/10.1038/ngeo2404.

Mackay, A. 1981. Climate and popular unrest in late medieval Castile. In: T.M.L. Wigley, M.J. Ingram, G. Farmer (Eds.), Climate and history. Studies in past climates and their impact on man. Cambridge University Press, Cambridge, pp. 356-376.

Matthews, J.A., Briffa K.R. 2005. The "Little Ice Age": Re-evaluation of an evolving concept. Geografiska Annaler. Series A. Physical Geography 87 (1), pp. 17-36. http://doi.org/10.1111/ j.0435-3676.2005.00242.x. 
Mauelshagen, F. 2010. Klimageschichte der Neuzeit 1500-1900. Wissenschaftliche Buchgesellschaft, Darmstadt, $144 \mathrm{pp}$.

Mauelshagen, F., Pfister, C. 2010. Vom Klima zur Gesellschaft. Klimageschichte im 21. Jahrhundert. In: H. Welzer, H.-G. Soeffner, D. Giesecke (Eds.), KlimaKulturen. Soziale Wirklichkeiten im Klimawandel. Campus, Frankfurt a. M., pp. 241-269.

McNeill,J.R. 2010. Mosquito empires. Ecology and war in the Greater Caribbean, 1620-1914.Cambridge University Press, Cambridge, XVIII+371 pp. https://doi.org/10.1017/CBO9780511811623.

Miller, G.H., Geirsdóttir, Á., Zhong, Y., Larsen, D.J., Otto-Bliesner, B.L. Holland, M.M., Bailey, D.A., Refsnider, K.A., Lehman, S.J., Southon, J.R. Anderson, C., Björnsson, H., Thordarson, T. 2012. Abrupt onset of the Little Ice Age triggered by volcanism and sustained by sea-ice/ocean feedbacks. Geophysical Research Letters 39, L02708. https://doi.org/10.1029/2011GL050168.

Neveux, H. 1974. Les grains du Cambrésis. Fin du XIVe-début du XVIIe siècles. Vie et déclin d'une structure économique. Mouton, Paris, 443 pp.

Newfield, T. 2009. A cattle panzootic in early fourteenth-century Europe. Agricultural History Review 57 (2), 155-190.

Ogilvie,A.E.J., Jonsson, T. 2001: "Little Ice Age" research: A perspective from Iceland. In: A.E.J. Ogilvie, T. Jonsson (Eds.), The Iceberg in the Mist: Northern Research in Pursuit of a "Little Ice Age". Kluwer Academic Publishers, Dordrecht, pp. 9-52. Reprinted from Climatic Change 48, pp. 9-52.

Parker, G. 2013. Global crisis. War, climate change and catastrophe in the seventeenth century. Yale University Press, New Haven, 871 pp.

Parry, M.L. 1981. Climatic change and the agricultural frontier. A research strategy. In: T.M.L. Wigley, M.J. Ingram, G. Farmer (Eds.), Climate and History. Studies in past climates and their impact on man. Cambridge University Press, Cambridge, pp. 319-336.

Pfister, C. 1975. Agrarkonjunktur und Witterungsverlauf im westlichen Schweizer Mittelland zur Zeit der Ökonomischen Patrioten 1755-1797. Ein Beitrag zur Umwelt- und Wirtschaftsgeschichte des 18. Jahrhunderts, Geographica Bernensia. Grundlagenforschung 2, Lang, Liebefeld, 229 pp.

Pfister, C. 1981a. An analysis of the Little Ice Age climate in Switzerland and its consequences for agricultural production. In: T.M.L. Wigley, M.J. Ingram, G. Farmer (Eds.), Climate and History. Studies in past climates and their impact on man. Cambridge University Press, Cambridge, pp. 214-248.

Pfister, C. 1981b. Die Fluktuationen der Weinmosterträge im Schweizerischen Weinland vom 16. bis ins frühe 19. Jahrhundert. Klimatische Ursachen und sozio-ökonomische Bedeutung. Schweizerische Zeitschrift für Geschichte 31, 445-491.

Pfister, C. 1984. Das Klima der Schweiz von 1525-1860 und seine Bedeutung in der Geschichte von Bevölkerung und Landwirtschaft, vol. 2: Bevölkerung, Klima und Agrarmodernisierung 15251860, Academica Helvetica 6, Paul Haupt, Bern, 163 pp.

Pfister, C. 1988. Fluctuations climatiques et prix céréaliers en Europe du XVIe au XXe siècle. Annales. Économies, Sociétés, Civilisations 43 (1), 25-53.

Pfister, C. 1999. Wetternachhersage. 500 Jahre Klimavariationen und Naturkatastrophen. Paul Haupt, Bern, 304 pp.

Pfister, C. 2004. Klimaverlauf und Agrarkonjunktur im weiteren zeitlichen Umfeld des Schweizerischen Bauernkrieges, 1550-1670. In: J. Römer (Ed.), Bauern, Untertanen und "Rebellen". Eine Kulturgeschichte des Schweizerischen Bauernkrieges von 1653. Kultur, Philosophie, Geschichte 2. Orell Füssli, Zürich, pp. 256-270.

Pfister, C. 2005. Weeping in the snow. The second period of Little Ice Age-type impacts, 1570-1630. In: W. Behringer, H. Lehmann, C. Pfister (Eds.), Kulturelle Konsequenzen der "Kleinen Eiszeit"/Cultural consequences of the "Little Ice Age". Veröffentlichungen des Max-Planck-Instituts für Geschichte 212, Vandenhoeck \& Ruprecht, Göttingen, pp. 31-86. 
Pfister, C. 2007a. Little Ice Age-type impact and the mitigation of social vulnerability to climate in the Swiss canton of Bern prior to 1800. In: R. Costanza, L.J.Graumlich, W. Steffen (Eds.), Sustainability or collapse? An integrated history and future of people on Earth. The MIT Press, Cambridge MA, pp. 197-212.

Pfister, C. 2007b. Climatic extremes, recurrent crises and witch hunts: Strategies of European societies in coping with exogenous shocks in the late sixteenth and early seventeenth centuries. The Medieval History Journal 10 (1-2). 33-73. https://doi.org/10.1177/097194580701000202.

Pfister, C. 2010. The vulnerability of past societies to climatic variation. A new focus for historical climatology in the twenty-first century. Climatic Change 101/1-2, Special Issue: European climate of the past 500 years based on documentary and instrumental data, R. Brázdil, D. Wheeler, C. Pfister (Eds.), pp. 281-310. https://doi.org/10.1007/s10584-010-9829-2.

Pfister, C., Brázdil, R. 2006. Social vulnerability to climate in the "Little Ice Age": An example from Central Europe in the early 1770s. Climate of the Past 2,115-129. https://doi.org/10.5194/cp-2-1152006.

Post, J.D. 1981. The impact of climate on political, social, and economic change. A comment. In: R.I. Rotberg, T.K. Rabb (Eds.), Climate and History. Studies in Interdisciplinary History. Princeton University Press, Princeton, pp. 139-144. https://doi.org/10.1515/9781400854103.139.

Rohr, C. 2005. The Danube floods and their human response and perception (14th to 17th C). History of Meteorology 2, Special issue: Diversity in the global reconstruction and representation of weather and climate: east, south, west, north. Selected papers from the ICHM Symposium at the International Congress of History of Science, Beijing, China, July 2005, L.K. McNally III, C. Rohr (Eds.). pp. 71-86, http://www.meteohistory.org/2005historyofmeteorology2/06rohr.pdf.

Rohr, C. 2006. Measuring the frequency and intensity of floods of the Traun River (Upper Austria), 14411574. Hydrological Sciences Journal 51 (5), pp. 834-847. https://doi.org/10.1623/hysj.51.5.834.

Rohr, C. 2007. Extreme Naturereignisse im Ostalpenraum. Naturerfahrung im Spätmittelalter und am Beginn der Neuzeit, Umwelthistorische Forschungen 4. Böhlau, Köln, 640 pp.

Rohr, C. (Ed.). 2008. Naturkatastrophen in der Geschichte. Wahrnehmung, Deutung und Bewältigung von extremen Naturereignissen in Risikokulturen, Historische Sozialkunde, Themenheft 2008/2, Verein für Geschichte und Sozialkunde, Wien 2008, 44 pp.

Rohr, C. 2009a. Confronting avalanches in the Alps in the late middle ages and early modern era. In: V. Jankovic, C. Barboza (Eds.), Weather, local knowledge and everyday life: Issues in integrated climate studies. Museu de Astronomia e Ciências Afins, Rio de Janeiro, pp. 67-74.

Rohr, C. 2009b. Sie Seind Krochen wie ain Kriegsordnung. Heuschreckenplagen im Land Tirol im Spätmittelalter und in der Frühen Neuzeit. Tiroler Heimatblätter 84 (1), 20-25.

Rohr, C. 2012a. Leben am und mit dem Fluss. Überschwemmungen der Traun im Raum Lambach in der Frühen Neuzeit. In: K. Landa, C. Stöttinger, J. Wührer (Eds.), Stift Lambach in der Frühen Neuzeit. Frömmigkeit, Wissenschaft, Kunst und Verwaltung am Fluss. Tagungsband zum Symposion im November 2009. Oberösterreichisches Landesarchiv, Linz, pp. 119-133.

Rohr,C.2012b.Stadterweiterung versus Naturgefahr. Die Stadt Wels während der Hochwasserkatastrophen von 1897 und 1899. Jahrbuch des Musealvereines Wels 36, 551-574.

Rohr, C. 2013. Floods of the Upper Danube River and its tributaries and their impact on urban economies (c. 1350-1600): The examples of the towns of Krems/Stein and Wels (Austria). Environment and History 19 (2), pp. 133-148. https://doi.org/10.3197/09673401 3X13642082568534.

Rohr, C. 2014. Coping with natural hazards in the Southeastern Alpine region in the middle ages and in early modern times. In: P. Štih, Ž. Zwitter (Eds.), Man, nature and environment between the Northern Adriatic and the Eastern Alps in premodern times. Zbirka Zgodovinskega časopisa 48. Znanstvena založba Filozofske fakultete, Ljubljana, pp. 290-313. 
Rotberg, R.I., Rabb, T.K. (Eds.). 1981. Climate and history. Studies in interdisciplinary history. Princeton University Press, Princeton, 280 pp. https://doi.org/10.1515/9781400854103.

Schenk, G.J., Engels, J.I. (Eds.). 2007. Historical disaster research. Concepts, methods and case studies/Historische Katastrophenforschung. Begriffe, Konzepte und Fallbeispiele. Historical Social Research 32 (3), Special Issue, 9-234.

Slavin, P. 2012. The great bovine pestilence and its economic and environmental consequences in England and Wales, 1318-1350. Economic History Review 65 (4), 1239-1266. https://doi. org/10.1111/j.1468-0289.2011.00625.x.

Slavin, P. 2017. Communities of famine: Environment, economy and society in early-fourteenth century Britain. Brepols, Turnhout.

Soens, T. 2013. Flood security in the Medieval and Early Modern North Sea area: A question of entitlement? Environment and History 19 (2), 209-232. https://doi.org/10.3197/0967340 $13 \mathrm{X} 13642082568651$.

Stern, D.V. 2000. A Hertfordshire demesne of Westminster Abbey. Profits, productivity and weather. Studies in Regional and Local History 1. University of Hertfordshire Press, Hatfield 2000, $256 \mathrm{pp}$.

Van der Wee, H. 1963. The growth of the Antwerp market and the European economy, fourteenthsixteenth centuries. 3 vols., Recueil de Travaux d'Histoire et de Philologie, Série 4, Fasc. 28-30. Bureau du Recueil, Bibliothèque de l'Université, Louvain.

Voss, M. 2008. The vulnerable can't speak. An integrative vulnerability approach to disaster and climate change research. Behemoth. A Journal on Civilisation 1 (3), 39-56. https://doi. org/10.1524/behe.2008.0022.

Wanner, H. 2016. Klima und Mensch. Eine 12'000-jährige Geschichte. Haupt, Bern, 276 pp.

Wetter, O., Pfister, C. 2013. An underestimated record breaking event - Why summer 1540 was likely warmer than 2003. Climate of the Past 9, 41-56. https://doi.org/10.5194/cp-9-41-2013.

Wetter, O., Pfister, C., Werner, J.P., Zorita, E., Wagner, S., Seneviratne, S.I., Herget, J., Grünewald, U., Luterbacher, J., Alcoforado, M.-J., Barriendos, M., Bieber, U., Brázdil, R., Burmeister, K.H., Camenisch, C., Contino, A., Dobrovolný, P., Glaser, R., Himmelsbach, I., Kiss, A., Kotyza, O., Labbé, T., Limanówka, D., Litzenburger, L., Nordli, Ø, Pribyl, K., Retsö, D., Riemann, D., Rohr, C., Siegfried, W., Söderberg, J., Spring, J.-L. 2014. The year-long unprecedented European heat and drought of 1540 - A worst case. Climatic Change 125, 349-363. https://doi.org/10.1007/s10584-014-1184-2.

White, S. 2011. The climate of rebellion in the early modern Ottoman Empire. Cambridge University Press, Cambridge, 352 pp. https://doi.org/10.1017/CBO9780511844058.

Wigley, T.M.L., Ingram, M.J., Farmer, G. (Eds.) 1981. Climate and history. Studies in past climates and their impact on man. Cambridge University Press, Cambridge, $530 \mathrm{pp}$.

Wigley, T.M.L., Huckstep, N.J., Ogilvie, A.E.J., Farmer, G., Mortimer, R., Ingram, M.J. 1985. Historical climate impact assessments. In: R.W. Kates, J.H. Ausubel, M. Berberian (Eds.), Climate impact assessment. Studies of the interaction of climate and society. Scope 27, John Wiley, Chichester, pp. 529-563.

Zwitter, Ž. 2015. Subsistence, prosperity and abandonment of Alpine isolated farms in the dynamic 17th century environment: Case study from the Upper Savinja Valley with special emphasis on tenants' inventories. Ekonomska i ekohistorija 11, Special Issue: History and Sustainability, 139-181. 